\title{
Radiographic measurement of cardiac size in laboratory mice
}

\author{
Mokhamad Fakhrul Ulum*, Deni Noviana \\ Department of Clinic Reproduction and Pathology, Faculty of Veterinary Medicine, Bogor Agricultural University
}

ABSTRACT: This study was to establish quantitative reference range measurements that could be used to support basic data of cardiac size in the laboratory animals. Right and left lateral recumbency (R/L view) and ventral and dorsal recumbency (VD/DV view) radiographs were obtained in 6 normally laboratory mice (Mus musculus). The R/L view heart measurements were the apicobasal length $(\mathrm{AB})$; the maximum width $(\mathrm{CD})$; the distance between the cranial edge of the fifth rib and the caudal edge of the seventh rib (R5-7); the vertical depth of the thorax (H). The VD/DV view cardiac silhouette measurements were maximum length $(\mathrm{L})$; maximum width $(\mathrm{W})$; the width of the thorax $(\mathrm{T})$. In order to determine vertebral heart scale score (VHS), the length and width of the heart were measured and then superimposed to the thoracic vertebrae starting at fourth vertebral (T4) caudally. In order to determine intercostals space (ICS), the CD were measured perpendicularly and superimposed on the intercostals space from fourth costal caudally. The cardiac silhouette was evaluated objectively to describe the cardiac appearance. Lengths of the parameter were determined with a caliper and a ruler in millimeters scale. The result showed that all measurements have not differed significantly between radiographic views $(\mathrm{p}>0.05)$.

Keywords:

mice, cardiac, radiography, heart, measurement

\section{- INTRODUCTION}

Determination of heart size is important for evaluating patients with heart disease in veterinary medicine. Thoracic radiographs are very helpful in the diagnosis of heart disease and provide information available with any other modalities (Gulanber et al. 2005). Reference heart size for healthy dog (Sleeper \& Buchanan 2001; Gulanber et al. 2005; Greco et al. 2008), ferret (Stepien et al. 1999), flying fox (Gardner et al. 2007) and cat (Litster \& Buchanan 2000) have been published. However, radiographic heart size in laboratory mice has no available yet publication. Therefore, the aims of this study to determine the reference range for heart size of healthy mice.

\section{- MATERIALS AND METHODS}

Animal laboratory and anesthetics agent: Six adult healthy with 30-40 grams body weight of mice (Mus musculus) was anaesthetized using ketamin- $\mathrm{HCl} 50 \mathrm{mg} / \mathrm{kg}$ body weight and xylazin- $\mathrm{HCl} 5 \mathrm{mg} / \mathrm{kg}$ body weight intraperitonial route. Radiography: The radiographic image was taken by using diagnostic portable $\mathrm{x}$-ray (VR 1020, MA Medical Corp., Japan). X-ray diagnostic setting on $0.8 \mathrm{mAs}, 50 \mathrm{kVp}$ and $100 \mathrm{~cm}$ film focus distance (FFD). The radiographic view in this study is right recumbence (Lview), left recumbence (R-view), dorsal recumbence (VDview), and ventral recumbence (DV-view).

Heart size measurement: All measurements were made with adjustable caliper and ruler. The measurements were modified from Gardner et al. (2007) were the apicobasal length of the heart $(\mathrm{AB})$; the maximal heart width perpendicular to $\mathrm{AB}(\mathrm{CD})$; the distance between the cranial edge of the fifth rib and the caudal edge of the seventh rib perpendicular to the spine at the level of the heart base (R57); the vertical depth of the thorax from the ventral border of the spine to the dorsal border of the sternum at the level of the tracheal bifurcation $(\mathrm{H})$ (Figure 1). The ratios $\mathrm{AB} / \mathrm{H}$, $\mathrm{AB} / \mathrm{R} 5-7, \mathrm{CD} / \mathrm{R} 5-7, \mathrm{CD} / \mathrm{H}$, and $\mathrm{AB} / \mathrm{CD}$ were calculated.

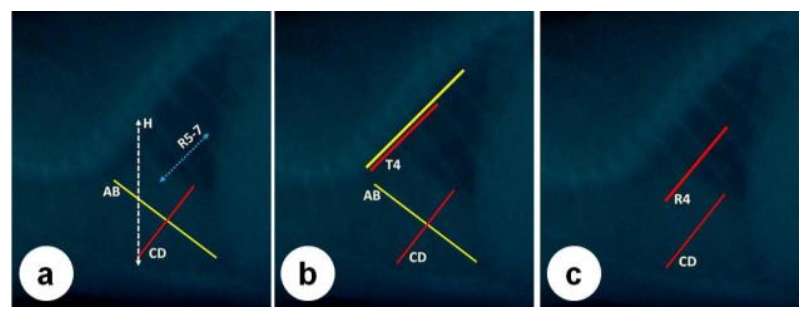

Figure 1. Lateral view radiographic of mice: general measurement (a), Vertebral Heart Size (VHS) (b), and Intercostal Space (ICS) (c).

To determine the vertebral heart-scale score (VHS), AB was measured on a lateral radiograph using calipers that were then superimposed on the thoracic vertebrae starting at T4. The distance between the caliper points was estimated to the nearest 0.25 vertebrae. The $\mathrm{CD}$ was measured against the thoracic vertebrae in the same manner. These two measurements were added to generate the vertebral heart scale score (Stepien et al. 1999; Litster \& Buchanan 2000; Sleeper \& Buchanan 2001). To determine the inter-costals space (ICS), CD was measured on a lateral radiograph were per-

Received: 10-12-2017 | Revised: 06-01-2017 | Accepted: 31-01-2018

(C) 2018 CC-BY-SA. This is an Open Access article that is distributed under the terms of Creative Commons Attribution ShareAlike 4.0 International License (https://creativecommons.org/licenses/by-sa/4.0/). 
pendicularly superimposed on the costals space from 4th costal caudally (Buchanan \& Bucheler 1995; Litster \& Buchanan 2000; Lamb \& Boswood 2002).

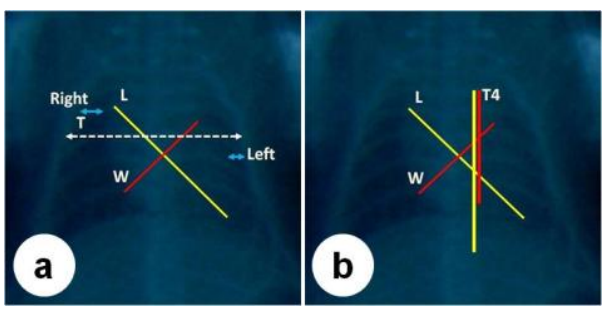

Figure 2. Ventrodorsal/dorsoventral view for radiographic of mice: general measurement (a) and Vertebral Heart Size (VHS) (b).

These measurements were maximum length of the cardiac silhouette (L); maximum width of the cardiac silhouette perpendicular to $\mathrm{L}(\mathrm{W})$; the width of the thorax at the point where rib six articulates with the vertebral column $(\mathrm{T})$. The following ratios were calculated: $\mathrm{L} / \mathrm{W}$, and W/T (Gardner et al. 2007). The VHS measured has same method in last describe for lateral recumbence (Figure 2).

Statistical analysis: Statistical analyses were performed using MINITAB software (v.14).

\section{RESULTS AND DISCUSSION}

Tabel 1 shows radiographic measurement of laboratory mice heart size and its ratio analysis. Generally, there are no differences between L- vs R-view and VD- vs DV-view measurement. Ghadiri et al. (2010) report that no significant differences could be found between the VHS of L-view and $\mathrm{R}$-view radiographs in mixed breed and native dogs.

Tabel 1. Radiographic measurement of laboratory mice heart size.

\begin{tabular}{|c|c|c|}
\hline Radiographic & \multicolumn{2}{|c|}{ View } \\
\hline Parameter & Left & Right \\
\hline 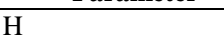 & $12.2 \pm 0.8$ & $12.3 \pm 1.0$ \\
\hline $\mathrm{AB}$ & $9.8 \pm 0.8$ & $9.3 \pm 0.5$ \\
\hline $\mathrm{CD}$ & $8.3 \pm 0.8$ & $7.5 \pm 0.5$ \\
\hline R5-7 & $5.8 \pm 0.5$ & $5.6 \pm 0.5$ \\
\hline VHS & $9.4 \pm 0.7$ & $9.1 \pm 0.5$ \\
\hline ICS & $3.4 \pm 0.5$ & $3.0 \pm 0.1$ \\
\hline Parameter & Ventrodorsal & Dorsoventral \\
\hline 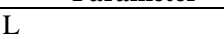 & $12.8 \pm 1.1$ & $12.7 \pm 1.7$ \\
\hline W & $8.8 \pm 0.7$ & $8.3 \pm 0.9$ \\
\hline $\mathrm{T}$ & $13.9 \pm 0.9$ & $14.5 \pm 1.3$ \\
\hline RIGHT SPACE & $3.0 \pm 1.0$ & $2.7 \pm 0.4$ \\
\hline LEFT SPACE & $1.5 \pm 0.0$ & $1.8 \pm 0.3$ \\
\hline VHS & $12.2 \pm 0.7$ & $12.6 \pm 0.7$ \\
\hline Ratio & Left & Right \\
\hline $\mathrm{AB} / \mathrm{R} 5-7$ & $1.7 \pm 0.1$ & $1.7 \pm 0.2$ \\
\hline $\mathrm{AB} / \mathrm{H}$ & $0.8 \pm 0.1$ & $0.8 \pm 0.1$ \\
\hline CD/R5-7 & $1.5 \pm 0.1$ & $1.4 \pm 0.2$ \\
\hline $\mathrm{CD} / \mathrm{H}$ & $0.7 \pm 0.1$ & $0.6 \pm 0.1$ \\
\hline $\mathrm{AB} / \mathrm{CD}$ & $1.2 \pm 0.1$ & $1.2 \pm 0.0$ \\
\hline Ratio & Ventrodorsal & Dorsoventral \\
\hline $\mathrm{L} / \mathrm{T}$ & $0.9 \pm 0.1$ & $0.9 \pm 0.1$ \\
\hline $\mathrm{W} / \mathrm{T}$ & $0.6 \pm 0.0$ & $0.6 \pm 0.0$ \\
\hline
\end{tabular}

A system of cardiac measurement was designed to take into account the cardiac size (Ghadiri et al. 2010). A guideline of intercostal spaces (ICS) for dogs was introduced in 1968 and it is still used in veterinary medicine. Limitations of this method include variations of the heart size and shape, conformation of the thorax, phase of respiration, superimposition of ribs, and imprecise measurement points (Buchanan \& Bucheler 1995; Litster \& Buchanan 2000; Lamb \& Boswood 2002). However, with the limitation, the measurement still can be conducted.

Buchanan and Bucheler (1995) have described a method for measuring vertebral heart score (VHS) and its developed originally as a screening test for cardiomegaly. Vertebral heart scale is a procedure that frequently used for increase the accuracy of the radiographic diagnosis of cardiac disease, particularly for inexperienced observers (Choisunirachon \& Kamonrat 2008).

\section{CONCLUSION}

No different size between radiograph views measurement. This technique is easy and objective for clinical practice in determining the heart size. Our study can be a guide in clinical practice for evaluating heart size in laboratory mice.

\section{- AUTHOR INFORMATION}

Correspondence author

*MFU: ulum@ipb.ac.id

Department of Clinic Reproduction and Pathology,

Faculty of Veterinary Medicine, Bogor Agricultural University, Bogor Jl. Agatis Kampus IPB Dramaga Bogor 16680

\section{- ACKNOWLEDGEMENT}

The authors would like thank to Andi Rahayu, Erli Chandra, and Fitria Apriliani, who's help radiography procedure.

\section{- REFERENCES}

Buchanan JW, Bucheler J. 1995. Vertebral scale system to measure canine heart size in radiographs. J Am Vet Med Assoc. 206:194199.

Choisunirachon N, Kamonrat P. 2008. Vertebral scale system to measure heart size in radiographs of shih-tzus. Proceedings 7 th Chula Univ Vet Sci Ann Con. 1 May, 2008

Gardner A, Thompson MS, Fontenot D, Gibson N, Heard DJ. 2007. Radiographic evaluation of cardiac size in flying fox species (Pteropus rodricensis, P. hypomelanus, and P. vampyrus). J Zoo Wildl Med 38(2): 192-200.

Ghadiri A, Avizeh R, Fazli Gh. 2010. Vertebral heart scale of common large breeds of dogs in Iran. Int J Vet Res. 4(2): 107-111.

Greco A, Meomartino L, Raiano V, Fatone G, Brunetti A. 2008. Effect of left vs. right recumbency on the vertebral heart score in normal dogs. Vet Radiol Ultrasound. 49:454-455.

Gulanber EG, Gonenci R, Kaya U, Aksoy O, Biricik HS. 2005. Vertebral scale system to measure heart size in thoracic radiographs of turkish shepherd (kangal) dogs. Turk J Vet Anim Sci: 29:723-726

Lamb CR, Boswood A. 2002. Role of survey radiography in diagnosing canine cardiac disease. Comp Cont Ed Prac Vet. 24:316-326.

Litster A, Buchanan JW. 2000. Vertebral scale system to measure heart size in radiographs of cats. J Am Vet Med Assoc. 216:210-214.

Sleeper MM, Buchanan JW. 2001. Vertebral scale system to measure heart size in growing puppies. J Am Vet Med Assoc. 219:57-59.

Stepien RL, Benson KG, Forrest LJ. 1999. Radiographic measurement of cardiac size in normal ferrets. Vet Radiol Ultrasound. 40:606610 . 